\title{
Burhânî Bilimlerin Konu, İlke ve Mesele Ayrımının İbn Sînâ ve Sonrasındaki Bazı Uygulamaları
}

\section{Arș. Gör. Dr. Haci Sağlık ${ }^{1 *}$}

Geliş tarihi: 25.11.2019

Kabul tarihi: 03.12.2019

\section{Atıf bilgisi:}

IBAD Sosyal Bilimler Dergisi

Sayı: $5 \quad$ Sayfa: $575-586$

Yıl: 2019 Dönem: Güz

This article was checked by Turnitin. Similarity Index 5\%

${ }^{1}$ Çukurova Üniversitesi İlahiyat Fakültesi, Türkiye,hsaglik@cu.edu.tr.

ORCID ID 0000-0002-2843-7576

* Sorumlu yazar

\section{ÖZ}

Aristoteles, ilk kez burhânî bilimler için konu, ilke ve mesele hususunu ele almıştır. Bu husus, ilk defa İslam felsefesinde İbn Sînâ tarafindan sistematik hale getirilmiş ve o, bu çerçevede bağımsız bir bilim olarak metafiziğin konu, ilke ve meselelerini ortaya koymuştur. Bu bağlamda, Ortaçağ İslam düşüncesinde müstakil olarak yeni bilimlerin ortaya çıkmasında bu metodolojinin yerinin ne olduğu konusu, üzerinde durulması gereken bir husus olmuștur. Aynı șekilde bu sistematiğin günümüz bilim anlayıșındaki yeri de merak konusudur. Bu çalışmamızda, bilimler için bilimsellik ölçütü olarak görülen konu, ilke ve mesele ayrımının Ortaçağ İslam düşüncesindeki metafizik, kelam, tasavvuf ve ümran ilmi bağlamında bazı uygulamalarını ele almaya çalıştık. Bu metodoloji çerçevesinde müstakil bilimlerin ortaya çıktığı ve bu anlayışın günümüzde de bilimler için temel kriter olduğu sonucuna vardık. Bunu ortaya koyarken sosyal bilimlerin ve felsefenin temel yöntemlerinden olan anlama, yorumlama, mukayese etme ve değerlendirmeye dayalı bir metot izledik.

Anahtar Kelimeler: İbn Sînâ, burhân, konu, ilke, mesele. 


\title{
Some Applications of the Distinction of Subject Principle and Investigation of Demonstration Sciences in Avicenna and After Him
}

\author{
Res. Assist. Dr. Haci Sağlık ${ }^{1^{*}}$
}

First received: 25.11 .2019

Accepted: 03.12.2019

\section{Citation:}

IBAD Journal of Social Sciences

Issue: $5 \quad$ Pages: 575-586

Year: $2019 \quad$ Session: Fall

This article was checked by Turnitin. Similarity Index 5\%

\author{
1 Çukurova University, Turkey, \\ hsaglik@,cu.edu.tr. \\ ORCID ID 0000-0002-2843-7576
}

* Corresponding Author

\begin{abstract}
For the first time, Aristotle has dealt with the subject, principle and investigation for the sciences of demonstration. For the first time this issue was made systematic by Avicenna in Islamic philosophy and in this context, he put forward the subjects, principles and investigations of metaphysic as an independent science. In this context, the issue of what is the role of this methodology in the emergence of new sciences in Islamic thought of the Middle Ages has been an issue to be emphasized. Likewise, the place of this systematic in today's understanding of science is a matter of curiosity. In this study, we discussed some applications of the distinction of subject, principle and investigation which are regarded as scientific criteria for the sciences in the context of metaphysic, kelam, sufism and umran in the Islamic thought in the Middle ages. Within the framework of this methodology, we have come to the conclusion that independent sciences emerge and this understanding is still the basic criterion for sciences. In doing so, we have followed a method based on understanding, interpretation, comparison and evaluation, which is one of the basic methods of social sciences and philosophy.
\end{abstract}

Keywords: Avicenna, demonstration, subject, principle, investigation. 


\section{Giriş}

Bilimleri birbirinden ayıran temel etken, onların konuları, izledikleri yöntem ve araştırma alanlarıdır. Bilimlerin inceleme alanı soyut ya da somut, zihinsel ya da duyusal olabildiği gibi, evren içinde ya da evren dışında bulunabilir. Bilimsel yöntemler ve konular, zorunlu olarak, inceleme alanının yapısına göre çeşitlilik arz eder. Bu çeşitlilik, diğer yandan, araştırma konularını da farklılaştırır. Böylece bilimsel bilgi; inceleme alanı, yöntem ve metot, konu ve alanın sorunları bakımından çok yönlü bir ilişki ağını gerekli kılar.

Aristoteles (M.Ö. 384-322) ve sonrasında bilimsel bilginin yöntemi, kesin çıkarım (apodeiktikos); İslam felsefesinde bilindiği adıyla burhândır. Aristoteles, ilk kez burhânî bilimleri konu, ilke ve meseleler temelinde incelemiştir. O, İkinci Analitikler'de bu hususla ilgili olarak şunları belirtir: "Burhânlar için üç şey vardır: Biri, kanttlanan şey yani sonuç (bu, bizzât bazı cinslere ait olan şeydir); biri, aksiyomlardır (aksiyomlar burhânın kendisine dayandlğg şeylerdir); üçüncüsü de burhânın, ilintilerini ve bizzât arâzî olanı açı̆̆a çıkardı̆̆ı konu olan cins." (Aristotle, 1991, 75a 39 75b 2). Buradan hareketle Aristoteles'e göre burhânî bilimlerin üç ana öğesi vardır. Bunların birincisi, kanıtlanması gereken ya da kanıtlanmaya ihtiyaç duyulan şeylerdir ki bunlar meselelerdir; ikincisi, burhânın kendisine dayandığı şeyledir ki bunlar da ilkeler; üçüncüsü de konudur. Aristoteles, burhânî bilimlerle ilgili olarak bu ayrımı Metafizik'te de belirtir: “...her burhânî bilim belli bir konu ile ilgili olarak aksiyomlardan hareket edip bu konunun özsel niteliklerini inceler." (Aristoteles, 2010, 997a 20-22). Burada aksiyomlar, temel öncüller iken özsel nitelikler ise bir bilimde ele alınan meseleler olmaktadir.

Aristoteles'in burhânî bilimler için ortaya koyduğu bu metodoloji İslam felsefesinde ilk defa Fârâbî (ö. 950)'de karşımıza çıkmaktadır. O, bilimleri teorik ve pratik olarak ayırdıktan sonra her nazarî sanatın, genel olarak konular, meseleler ve ilkeler olmak üzere üç şeyi kuşattığını belirtir. $O$, bir sanatın konularının, zâtî arâzların kendileri için var olduğu ve o sanatta incelenen diğer şeylerin daha önce zikredilen nispet tarzlarından biriyle kendilerine nispet edildiği şeyler olduğunu belirtip örnek olarak da Aritmetik ilminin konusunun sayı, Geometrinin ise çizgiler, yüzeyler ve cisimler olduğunu ifade eder. Fârâbî, bir sanatın meselelerinin, o sanatta kanıtlanacak şeyler; bir sanattaki ilk ilkelerin ise, o sanatta kanıtlanması mümkün olmayan öncüller olduğunu beyan etmektedir (Fârâbî, 2012, s. 36).

İlk defa Aristoteles tarafindan ortaya konulan ve İslam felsefesinde Fârâbî tarafindan da kabul gören, burhânî bilimlerin bilimsellik ölçütü olan konu ilke ve mesele ayrımı metodolojisini detaylı bir şekilde ele alıp onu sistematize eden kişi İbn Sînâ olmuştur.

Bilimlerin, konu, ilke ve mesele ayrımı sistematiği ile ilgili olarak daha önce bazı çalışmalar yapılmıştır. Bu çalışmalar genellikle ya Daşdemir'in yaptığı gibi bu sistematiğin kişi bazında mantıksal çerçevesini çizmek ${ }^{1}$ ya da Türker'de olduğu gibi bir bilim dalının konu ve meselelerinin tespit edilmesi ya da tartışılması ${ }^{2}$ şeklinde yapılmıştır. Biz bu çalışmamızda özetle bir şekilde bu metodolojinin mantıksal çerçevesini verdikten İbn Sînâ ekseninde bunun metafiziğe tatbikini ele ele alçağız. Daha sonra İbn Sînâ sonrasında bu ayrımın kelâm, tasavvuf ve ümran ilmi gibi bazı bilimlerdeki yansımasını tarihsel sıralamayı baz alarak irdeleyeceğiz. Bu şekilde, bilimlerin bağımsız olarak ortaya çıkmasında bu metodolonin rolü ve öneminin tarihsel arka planını bilimler bazındaki tatbikini ele alarak ortaya koymak ve böylece bunun günümüzdeki fonksiyonunu ve dönüşümünü belirtmek bu çalışmanın ayırt edici özelliği olacaktır.

\section{1. İbn Sînâ'da Burhânî Bilimlerin Bilimsellik Ölçütü ve Metafizikteki Uygulaması}

İbn Sînâ, Aristoteles'in burhânî bilimler için ortaya koyduğu konu, ilke ve mesele ayrımını, diğer felsefî bilimleri kapsayacak ve daha ayrıntılı bir şekilde ele alarak belli bir çerçeveye oturtmuştur. O,

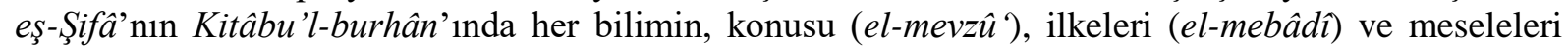
(el-mesâil/el-metâlib) olmak üzere üç boyutu olduğunu belirtir. Ona göre konu, ilgili bilim tarafından herhangi bir ispata ihtiyaç duyulmayan hallerdir. İlkeler, bir bilimin kendisinden burhân getirildiği ve o bilimin aslını oluşturan öncüllerdir (mukademât) ki bunlar genel ya da özeldir. Meseleler ise

\footnotetext{
${ }^{1}$ Bu konu ile ilgili olarak bkz. (Daşdemir, 2012, s. 240-261).

${ }^{2}$ Bununla ilgili olarak bkz. (Türker, 2008, s. 233-236; Türker, 2006, s. 33-40).
} 
yüklemleri konunun, konunun türlerinin veya arâzlarının zâtî ilişenleri olan önermelerdir ki bu önermeler araştırılmaya ve ispat edilmeye muhtaçtır (İbn Sînâ, 2006, s. 102).

İbn Sînâ, Dânişnâme-i 'alâ̂̀'nin "Mantık” bölümünde de bu konuyu şu şekilde ifade eder: "Her burhân̂̂ ilmin üç öğesi vardır: Birine konu (mevzu'), birine zâtî arâzlar (âsâr-i zâtî), birine de ilke (mebâdî) denir. Konu, ilgili ilim içinde durumu gözetilen şeydir. Insan bedenini tıbba, sayının aritmetiğe, sesin müziğe konu olmasl gibi. ... Zâtî arâzlar, o ilmin dışında değil, onun konusunda meydana gelen hususiyetlerdir. Tipkı üçgen ve dörtgenin bazı ölçülere, doğru ve eğrinin de bazı ölçülere ait olması gibi. ...Illkeler, o ilmin aslını oluşturan öncüllerdir. Öğrencinin o ilmi öğrenmesi için önce bu ilkelere inanması gerekir" (İbn Sînâ, 1391(hş.), s. 88-89).

Görüldüğü üzere İbn Sînâ, her burhânî ilmin konu, mesele ve ilkelerinin olduğunu belirterek bir çerçeve çizmektedir. $\mathrm{O}$, çizdiği bu çerçeve bağlamında metafizik ilminin konu, ilke ve meselelerini ortaya koymaktadir.

\subsection{Metafiziğin Konusu}

Aristoteles, konuyu, bir bilimin kendi varlığını ortaya koyduğu şey, cins olarak tarif eder (Aristotle, 1991, 76b 12-15). Bu bağlamda o, metafiziğin konusunun 'varlık olmak bakımından varlık' olduğunu şöyle ifade eder: "Varlık olmak bakımından varlı̆̆l ve ona özü gereği ait olan ana nitelikleri inceleyen bir bilim vardır. Bu bilim özel bilimler diye adlandırılan bilimlerin (fizik, matematik) hiçbirinin aynısı değildir. Çünkü diğer bilimlerden hiçbiri genel olarak varlı̆̆ varlık olmak bakımından ele almaz; tersine onlar örneğin matematik bilimlerinin yaptıkları gibi, varlı̆̆ın belli bir parçasını ayırarak sadece bu parçasının ana niteliklerini inceler (Aristoteles, 2010, 1003a 20-26)."

Konuyu, ilgili bilim tarafından, herhangi bir ispata ihtiyaç duyulmayan şeyler olarak kabul eden İbn Sînâ, metafiziğin konusunun eş-Şifâ' da Aristoteles gibi 'varlık olması bakımından varlık' (el-mevcûd bi mâ huve mevcûd) (İbn Sînâ, 2005, s. 6 ve 9); Dânişnâme-i 'alầ' de de 'mutlak olması yönünden mutlak varlık' (hestî mutlak est ez ân cihet ki vî mutlak est) olduğunu belirtir (İbn Sînâ, 1383/2004, s. 6). Bu ifadeler varlıkta doğal olarak tekil şeyleri dışarıda bırakır; ancak 'mutlak olması yönünden mutlak varlık' ya da 'varlık olması yönünden varlık' bize neyi ifade etmektedir?

Metafizik varlığı cüz’î olarak ya da bir yönüyle ele almaz; o varlı̆̆ı mutlak olarak sırf varlık olması açısından ele alır. Varlığın mutlak olması veya varlık bakımından varlık, onun en genel ve her şeyi kapsayan ortak bir kavram olması, hiçbir şekilde maddeye dayanmaması ve bir bölünmeye konu olmaması hasebiyle göz önünde bulundurulmasıdır. Çünkü o, apaçık bir gerçekliktir; bunun için onun mahiyetinin araştırılmasına veya ispat edilmesine ihtiyacı yoktur (İbn Sînâ, 2005, s. 9-10; Hânsârî, 1356 (hş.), s. 7-9.).

Yani apaçık olan en genel şey, varlıktır. Bir bilimin konusunun o bilimde ispatlanmasına ihtiyaç duyulamayan bir mahiyette olması gerektiğinden ve metafiziğin de diğer bilimlerin en üstünü olduğundan mutlak varlık da ancak bu bilimin konusu olabilir.

\subsection{Metafiziğin Meseleleri}

Aristoteles, meseleyi, “her biri için, bir ilmin manasını ortaya koyduğu ilintiler (Aristotle, 1991, 76b 15)" şeklinde tarif ederken İbn Sînâ bir bilimde kuşkulu olan ve hakkında burhân getirilmeye ihtiyaç duyulan önermeler olarak tanımlar ((İbn Sînâ, 1992, I, s. 89). Ona göre bu tür önermeler ya bir bilimin konusu, ya da zâtî arâzlarıdır. Eğer bilimin konusu ise ya bizzât konu olur ya o bilimin konusu zâtî arâzıyla beraber olur yahut da konunun türü olur veyahut da konunun türü zâtî arâzla beraber olur. $\mathrm{Bu}$ şekilde İbn Sînâ, burhânî bilimlerin meselelerinin önermelerini beş gruba ayırmaktadır:

a) 'Bizzât konu olan önermeler: Örneğin 'her ölçü kendi cinsdaşı olan ölçüyle ortaklığa sahiptir.'

b) Konunun zâtî arâzıyla beraber olduğu önermeler: Örneğin 'farklı miktarlara sahip olan her ölçü farkl1 sayılara sahiptir.'

c) Konunun türü olan önermeler: Örneğin 'altı tam bir sayıdır.'

d) Konunun türü zâtî arâzıyla beraber olan önermeler: Örneğin, 'bir doğru üzerine bir doğru daha konulduğunda iki dik açı oluşur.' 
e) Zâtî olan önermeler: Örneğin, 'üçgenin tüm açıları toplamı iki dik açıya eşittir’” (İbn Sînâ, (1391(hş.), s. 89-90; Mekrabî, 1391 (hş.), s. 153).

Dânişnâme-i 'alâı̀'nin Mantık bölümünde burhânî bilimlerin meselelerinin kısımlarını bu şekilde açıklayan İbn Sînâ, eş-Şifâ'nın Illâhiyyât'ında da metafiziğin konusu ve mesâillerini tartışmaya açıp daha önce metafizikte konu olarak kabul edilen şeyleri bir elemeden geçirerek metafiziğin konusunu ve mesâillerini birbirinden ayırıp net bir tablo önümüze koymaktadır.

Ona göre Tanrı, metafiziğin konusu olamaz; çünkü her bilimin konusu ontolojik olarak metafizikte kabul edilmiş ve temellendirilmiş bir varlık alanıyla ilgili olup, söz konusu bu bilimler ancak o varlık alanıyla ilgili halleri incelerler. Oysa Tanrı'nın varlığı metafizikte temellendirilmesi gereken ve kabul edilen bir konudan ziyade metafiziğin kanıtlamak için ele aldığı bir problemdir. Tanrı'nın varlığı kendiliğinden açık değildir; ancak O'nun varlı̆̆ının kanıtları vardır ve bu kanıtları ortaya koyarak problemi ele almak metafiziğin bir meselesidir. Tanrı hakkında yapılacak metafizik araştırma ise O'nun varlığı ve sıfatları hakkında olacaktır ki bunlar konu değil; ancak ele alınması gereken problemlerdir; çünkü hiçbir bilim kendi konusunu ispatlamaya çalışmaz (İbn Sînâ, 2005, s. 3-4).

İbn Sînâ'ya göre sebeplerin varlığı, dört sebep ve varlıkların uzak sebepleri de metafiziğin konusu değil, metafizikte incelenen problemlerdir (İbn Sînâ, 2005, s. 5-6). Çünkü sebep kavramının öncelikle ispatlanmaya ihtiyacı vardır. Aynı şekilde varlık alanında sebep ile müsebbeb fikri açık-seçik değil, deney ve gözlem sonucu elde edilebilen bir fikirdir. Açık-seçik olmayan ve burhânla ortaya konulması gereken şeyler de metafiziğin konusu olamaz, ancak meselesi olur (Kutluer, 2002, s. 73; Türker, 2014, s. 17-19.

İbn Sînâ'ya göre tikel bilimlerin ilkelerinin oluşturulması da metafizikte incelenmesi gereken meselelerdir (İbn Sînâ, 1383/2004, s. 8). Ona göre daha özel bir bilimin ilkeleri daha yüce bir bilimin meseleleri olduğu için bütün bilimlerin en yücesi olan metafizikte, tikel varlıkların hallerini inceleyen tikel bilimlerin ilkeleri incelenir (İbn Sînâ, 2005, s. 11).

İbn Sînâ, varlığa ilişen ve böylece metafizikte incelenmesi gereken ve araştırma konusu olan şeyleri şöyle detaylandırmaktadır:

a) Şeyin ve mevcûdun, yokluğun ve zorunluluğun durumu, imkânın durumu ve hakikati, bilkuvve ve bilfiil olma durumu, bizzât ve bilarâz olma durumu, hak ve batıl, cevher ve kısımları, arâz ve kısımları, tümel ve tikel, bütün ve parçanın durumu, cins ve tür, illet ve ma'lûl, etki ve edilgi, sûret ve gaye arasındaki farkın belirlenmesi, ilke ve başlangıç, öncelik ve sonralık, hâdislik ve onun türleri, bir ve çok, sayı, sayının mevcûdlarla ilişkisi ve mevcûdların ilkeleri (İbn Sînâ, 2005, s. 19-21; İbn Sînâ, 1383/2004, s. 7-8).

b) İlk İlke'yi, yani her şeyin yaratıcısını tanıma, O’nun birliği ve her şeyle bağlantısını; yani tevhidi ele alan İlâhî bilim veya Rubûbiyet ilmi (İbn Sînâ, 1383/2004, s. 8), İlk İlke'nin sıfatları ve O'nun hakkında gerçeğe aykırı söylenmiş sözleri çürütmek.

c) Zorunlu Varlık'tan sudûr eden varlıklar, melekî-aklî, melekî-nefsanî ve melekî-göksel cevherler, varlıkların İlk İlke'den nasıl sudûr ettiği ve O'na nasıl döneceği, ölüm ve ölüm sonrası nefsin durumu, peygamberlik, uhrevî mutluluğa ulaşmak için yapılması gereken eylem ve mutluluk türleri metafiziğin kendisine problem ettiği ve incelediği şeylerdir (İbn Sînâ, 2005, s. 21-22).

Metafizikte incelenen alanlardan hareketle İbn Sînâ, bu bilimi dört kısma ayırmakta ve böylece metafiziğin mesâillerini de özetlemektedir:

a) "Uzak sebepleri inceleyen metafizik: Uzak sebepler, nedenli olan her varlığın varlığı bakımından sebepleridir.

b) İlk Sebeb'i inceleyen metafizik: İlk Neden, kendisi dışındaki varlıkların nedenli varlık oluşları bakımından kendisinden taştığı ilk sebeptir ki bu sebep yukarıda da belirttiğimiz gibi Tanrı'dır.

c) Varlığın arâzlarını inceleyen metafizik.

d) Tikel bilimlerin ilkelerini inceleyen metafizik" (İbn Sînâ, 2005, s. 11). 


\subsection{Metafiziğin İlkeleri}

Aristoteles, bir şeyi ispat etmenin yolunun, kanıtlanmaya ihtiyaç duyulmayan ilk öncüllerin var olmasından geçtiğini; aksi takdirde döngüsel kanıtlamaların ortaya çıkacağını ve bunun da imkânsıza götüreceğini belirtir. Bunun için ispatın daha önce gelen ve daha iyi bilinen öncüllerden oluşması zorunluluğu vardır Aristotle, 1991, 72b 19-29).

İbn Sînâ da herhangi bir aracı olmaksızın tasavvur veya tasdîk edilenlerin, sonraki tasavvur ve tasdîkler için ilk öncüller olması gerektiğini vurgular. Çünkü her öğrenme ve öğretme önceki bir bilgiyle olursa bu durum sonsuza dek gider ve dolayısıyla ortaya bir öğrenim ve öğretim çıkmaz (İbn Sînâ, 2006, s. 26). Bunun için bilginin kendisine dayandığ 1 ve burhâna ihtiyaç duymayacak şekilde zorunlu bilgilerin olması gerekir. Bunlar da burhânın ilkelerinin sonunda gelip dayandığı temel öncüllerdir (İbn Sînâ, 2006, s. 66).

Aristoteles, ilkeyi, burhânın kendisinden çıktığı ilk öncüller olarak tanımlamakta (Aristotle, 1991, 76b 14-15) ve ilkeleri kapsamı bakımından 'bir bilime has olan' ve 'ortak olan ilkeler' şeklinde ikiye ayırmaktadır (Aristotle, 1991, 76a 38-39). Bunun yanı sıra ilkeleri bir de kesinlik bakımından 'sav' ve 'aksiyom' şeklinde tasnif etmektedir. Sav, doğrudan ispatlanamamakla beraber, birinin bir șeyi öğrenmesi için bilinmesi zorunlu olmayan; aksiyom ise zorunlu olandır. Savlar bir şeyin ya olacağı ya da olmayacağını konu edinirse 'varsayım'; bundan bağımsız ise 'tanım'dır (Aristotle, 1991, 72a 1521).

Burhânî bilimlerin ilkeleri konusunda Aristoteles, İbn Sînâ'ya da kaynaklık etmektedir. Nitekim o, eşŞifâ'nın Burhân kitabında burhânî bilimlerin ilkelerinin çerçevesini çizmiş, bunu yaparken Aristoteles'ten daha açıklayıcı bilgiler vererek konuyu daha sistematik bir şekilde ele almıştır. Ona göre ilkeler: "Bir bilimin kendilerinden kanıtlandığı veya açıklığı nedeniyle ya da o bilimde kanıtlanmayacak ve ancak o ilimden daha yüce bir bilimde kanitlanacak kadar yüceliği nedeniyle yahut da o bilimde kanıtlanmayacak ve ancak onun daha aşağısındaki bir bilimde kanıtlanacak kadar düşüklüğü nedeniyle -ki bu nadirdir- o bilimde açıklanmayan öncüllerdir (İbn Sînâ, 2006, s. 102).” $\mathrm{Bu}$ tanımdan ortaya çıkan sonuç, ilkelerin, bilimlerin kendilerinden kanıtlandığı; yani kendisinden burhân getirildiği öncüller olduğu ve her bilimin ilkelerinin -istisnalar dışında- kendisinden daha üstün bir bilimde açıklandığı iddiasıdır ki İbn Sînâ'ya göre metafizik en yüce bilim olması hasebiyle tikel bilimlerin ilkeleri bu bilimde incelenmektedir (İbn Sînâ, 2005, s. 11).

İbn Sînâ, Aristoteles gibi, burhânî ilkeleri kapsamına göre özel ve genel ilkeler olmak üzere ikiye ayırmaktadır:

a) Özel İlkeler: Bu ilkeler her bir bilime has olan ilkelerdir. Örneğin, 'hareket vardır,' ilkesi fiziğe özgü; 'her ölçü sonsuza dek bölünebilir' ilkesi matematik bilimine özgüdür. İbn Sînâ'ya göre özel ilkelerin konuları o bilimin konusudur, ya da o bilimin konularının türleridir yahut da o bilimin konularının parçaları veya özel ilişenleridir.

b) Genel İlkeler: Bütün bilimler veya birkaç bilim için geçerli olan ilkelerdir. 'Bir şey ya vardır ya da yoktur,' ilkesi bütün bilimler için geçerli bir ilke iken; 'bir şeye eşit olan şeyler, birbirine de eşittir,' ilkesi ise geometri, aritmetik, astronomi gibi bilimlerde geçerli olan ortak bir ilkedir (İbn Sînâ, 2006, s. 102-103).

İbn Sînâ, kesinlik bakımından ise ilkeleri dört kısma ayırmaktadır:

Birincisi, tanımdır. İbn Sînâ, tanımı bir şeyin mahiyetini ortaya koyan söz olarak tarif eder ve tanım kesin bilgi verir.

İkincisi, İbn Sînâ'nın bilinen ilim (ilm-i mute 'ârif) ve kapsayıcı ilim (ilm-i câmi ') dediği kendisinden şüphe duyulmayan, zorunlu ve ilksel öncüllerdir ki bunlara aksiyom adı da verilir. 'Eşit olan şeylerin yarıları da birbirine eşittir' ilkesi bir aksiyomdur.

Üçüncüsü, İbn Sînâ'nın 'asl-i mevzû'' dediği, kendisinde şüphe bulunan, öğrenenin kabul ettiği; fakat doğruluğu başka bilimde elde edilen öncüldür.

Dördüncüsü ise öğrenenin müsamaha gösterdiği ve zit bir görüşünün olmadığ 'müsâdere' adı verilir (İbn Sînâ, 1391(hş.), s. 92). 
Bütün bunlardan hareketle metafiziğin temel ilkeleri “- Varlık vardır. - Yokluk yoktur. - İlk İlke'nin varlığı zorunludur. - Her sonucun bir nedeni vardır. -Mümkün, var olması ya da var olmaması imkân dâhilinde olandır. -İmkânsız, var olmaması zorunlu olandır." gibi aklın kabul ettiği ve mantık ilminin temel kuralları olan tüm ilkelerdir. Zira mantık ilmi insana, var olan bilgilerden hareketle yeni bilgiler elde etme işlemini ve elde edilen bilgilerin özelliklerini ve bu bilgileri düzgün ve sistematik bir şekilde kullanma yöntemini öğreten bir ilimdir (İbn Sînâ, 2005, s. 2). Bunun için mantığın ortaya koyduğu ilkeler aynı zamanda metafiziğin temel ilkeleridir.

\section{Burhânî Bilimlerin Bilimsellik Ölçütünün İbn Sînâ Sonrasındaki Bazı Uygulamaları}

Aristoteles'in ilk defa çerçevesini çizdiği, İbn Sînâ'nın ise detaylandırarak daha da sistematik hale getirdiği ve metafiziğge tatbik ettiği burhânî bilimlerin bilimsellik ölçütü olarak "konu, ilke, mesele" bahsi İbn Sînâ'dan sonra da kabul görmeye ve uygulanmaya devam etmiştir.

İslam düşünce tarihinde İbn Sînâ sonrasında bu metodolojiyi kısmen uygulayan düşünürlerden biri Ebû Hâmid el-Gazzâlî (ö. 1111)'dir. O, el-Mustasfâ adlı eserinde ilimleri ilk önce sırf aklî, sırf naklî (dinî) ile hem aklî hem de naklî olan olmak üzere üçe ayırmakta (Gazzâlî, 1994, s. 2), daha sonra da bunları kendi aralarında küllî ve cüz'î şeklinde ayırmaktadır (Gazzâlî, 1994, s. 4). Hangi ilim olursa olsun bir ilmi iyi öğrenmek için her şeyden önce onun konu ve temel ilkelerinin iyi bilinmesi gerektiğini vurgulayan (Gazzâlî, 1994, s. 2) Gazzâlî buradan hareketle dinî ilimler içerisinde kelam ilminin küllî, diğerlerinin ise cüz'î ilimler olduğunu belirterek kelamın konusunun var olan (mevcûd); tefsirin, Kur'an'nın anlamı; hadisin, hadis tespit yolu; fikhın, fiillerin hükümleri olduğunu belirtir (Gazzâlî, 1994, s. 4). Bu eserinde aklî ilimlerin konuları hakkında herhangi bir şey beyan etmeyen Gazzâlî'nin kelamın konusunu mevcûd olarak kabul etmesiyle onu metafiziğin karşısına koyduğunu görüyoruz. O, kelamın, mevcûdu, ilk önce kadîm ve hâdis olmak üzere ikiye ayırdığını, daha sonra hâdisi de cevher ve arâz, yine bunları da alt birimlere ayırarak incelediğini belirtir. O, kelamın daha sonra da kadîmi ele aldığını belirtir ki bu da ona göre Allah'tır. Burada kadîmin sıfatları ve O'nun âlemle olan ilişkisi incelenir (Gazzâlî, 1994, s. 4). Böylece o, açıkça belirtmese de kelamın temel meselelerine vurgu yapmıştır. Gazzâlî, kelamın dinî ilimler içerisinde küllî bir ilim olması hasebiyle onların ilkelerinin de kelam tarafından ortaya konulduğunu belirtir (Gazzâlî, 1994, s. 5-6). Bu şekilde onun, kelama dinî ilimler için bir çatı görevi vererek metafiziğin yüklediği görevi ona uygulamaya çalışmıştır.

Gazzâlî' den sonra bilimlerin bilimsellik kriterlerinin Sirâcuddîn el-Urmevî (ö. 682/1283) tarafindan da ele alındığını görüyoruz. Urmevî, Risâletü fì'l farki'l beyne nev 'ey el-ilmi'l-İlâhî adlı risalesinde her bilimin bir konusu; konu içerisinde hakkında burhân getirilen meseleleri ve kendisinden burhânlar yapılan ilkeleri olduğunu belirtir. Ona göre bir bilimin konusu, o bilim tarafindan kabul edilen, yani üzerinde uzlaşılan şeydir. (Urmevî, 2009, s. 95-96). Urmevî’ye göre metafiziğin konusu ne özel bir mevcûd olarak Allahu Te'âlâ, ne de hem mutlak neden olması hem de özel neden olması bakımından ilk nedenlerdir. Metafiziğin konusu mevcûd olması bakımından mevcûdtur (Urmevî, 2009, s. 96). Buradan hareketle Urmevî de İbn Sînâ gibi Allah'ın varlığının bizzât açık olmadığından metafiziğin konusu olamayacağını, O'nun ancak metafizikte araştırılan bir konu olabileceğini ifade eder. O, metafiziğin Allah hakkında deliller ortaya koyduğundan ve madde ile maddeden ayrık olan şeyleri incelediğinden- ki Allah da madde ve onunla ilgili şeylerden en uzak olandır- O'nun metafiziğin konusu değil bir meselesi olduğunu belirtir (Urmevî, 2009, s. 97). Urmevî, metafizikte incelenen meseleleri de özetle maddeden ve maddeyle bağlantılı şeylerden uzak (berî) olanlar, madde kurucu unsur olmaksızın maddeyle karışık olanlar, nedensellik ve birlik gibi maddede var olmayan ile hareket ve durağanlık gibi maddesel olup ancak varlık açısından incelenen şeyler şeklinde sıralamaktadır (Urmevî, 2009, s. 100). Metafiziğin konu ve meselelerini İbn Sînâ gibi ele alan Urmevî, daha sonra bu metodolojiyi kelama uygular. Ona göre kelamın konusu Allah'ın inniyeti ve varlığıdır. Çünkü O'nun varlığı kelamda kabul görmüsşür (Urmevî, 2009, s. 101). O, kelamın konusunu tespit ettikten sonra onun meselelerini de O'nun selbî sıfatları; subûtî sıfatları; evrenin yaratılması, kader, nübüvvet gibi dünyayla bağlantılı olan işler ile ahirete dair olan şeyler olarak belirtir.(Urmevî, 2009, s. 103). Bu şekilde Urmevî, metafizik ile kelamın konu ve meselelerini birbirinden ayırarak kelamın konumunu ortaya koymuştur. 
Urmevî'nin çağdaşı ve arkadaşı Sadreddîn el-Konevî (ö. 673/1274) nin ise, İbn Sînâ'nın genel bilimler ve metafizik için, Urmevî'nin de metafizik ve kelam için ortaya koyduğu konu, mesâil ve ilke ayrımını kabul ederek, ilgili metodolojiyi tasavvufa tatbik ettiğini görüyoruz. O, Miftâh-ı gaybi'l-cem ve'lvucûd adlı eserinde her ilmin mevzu, ilke ve meseleleri olduğunu ifade eder. Ona göre mevzu, metafizikte varlık, geometride ölçü olduğu gibi kendisinde, o ilmin hakîkatinden, o ilme ait hallerden ve zâtından dolayı ona arız olan konulardan bahsedilen şeydir. Konevî, ilkeleri de mantıktaki tasavvur ve tasdîkler olarak kabul eder. Ona göre tasavvurlar, tanımlardır; tasdikler ise ilmin üzerine inşa edildiği öncüllerdir. Meseleler ise hakkında burhân getirilen ve muhatap için ispata ihtiyaç duyulan şeyler olup bunlar, ya o ilmin kapsadığı bütün şeylere ait olan asıllardır ya da türler ve türlerin de türleri gibi asılların altında yer alan ferdî şeylerdir. (Konevî, 2002, 2002, s. 7-8).

$\mathrm{Bu}$ ana çatıdan hareketle Konevî, tasavvufun (el-ilmu'l-ilâhî) konusunun her şeyi kuşatan Hakk'in varlığı olduğunu ifade eder (Konevî, 2002, s. 2002, s. 9). Türker'e göre, çünkü el-Konevî, varlık kavramıyla tek bir şeyi ifade eder ki bu varlık da her şeyi kuşatan Allah'ın varlığıdır (Türker, 2008, s. 235). Bu şekilde o, İbn Sînâ'nın, metafiziğin konusunun varlık olmak bakımından varlık olarak tesbitini tasavvufta, varlık olmak bakımından varlığı Allah'a indirgeyerek İbn Sînâ'ya karşı farklı bir yaklaşım geliştirmiştir (Demirli, 2007, s. 33).

el-Konevî'ye göre tasavvufun ilkeleri Allah'ın isimleridir. Ona göre bunlar zât isimler, sıfat isimler ve fiil isimler olmak üzere üç çeşittir. Hakk'ın varlığının kendileriyle ortaya çıktığı zât isimler, hükmü bu dünyada ortaya çıkan, Hakk'ın kendileriyle bilindiği isimler ve Hakk'ın eser perdesinin ardında olan isimler olmak üzere iki çeşittir. Tasavvufun meseleleri de Hakk ile âlem arasındaki karşılıklı irtibat ve bu irtibatın sorunlarıdır (Konevî, 2002, s. 9-10). Şüphesiz bu yaklaşım el-Konevî'de gerek tasavvufun konusunun ve ilkelerinin gerekse meselelerinin Allah'ın varlığı ekseninde şekillendiğini göstermektedir. Zira Konevî, varlık kavramıyla sadece kendisinin kastedildiği ve O'nun, her şeyi kuşattığı anlayışından hareketle Allah'ı tasavvufun konusu olarak kabul etmesiyle bu ilmi merkezi bir konuma koymuştur. O buradan hareketle de her ilmin konusunun tasavvufun konusunun ferî, ilkesi ve meselelerinin de tasavvufun mevzu ve ilkelerinin ferî olduğu (Konevî, 2002, s. 9) sonucuna varmaktadir.

Konevî'den sonra Dâvûd-i Kayserî (ö. 751/1350) 'de de bilimlerin konu, ilke ve mesele ayrımı metodolojisini görüyoruz. O, Risâle fi ilmi't-Tasavvuf ve şerhu te'vilatı besmele adlı eserinin birinci faslında her ilmin konu, mesele ve ilkelerinin olduğunu belirterek ilimlerin konuları itibariyle birbirinden ayrıştığını ifade etmektedir. Ona göre bir ilmin konusu, kendisinde o ilmin zâtî arâzlarının araştırıldığ 1 şey, arâzlar ise o ilmin meseleleridir. O, ilkeleri de şöyle açıklar: "Bir ilmin meselelerinin tamamı ya bedihî, ya kesbî ya da bir kısmı bedihî bir kısmı kesbîdir. Şayet meselelerin tümü bedihî ise bu durumda bunlar diğer ilimlerin ilkeleridir. Eğer tümü kesbî ise bu durumda kesbî meseleler, kendileriyle bilindikleri bedihî durumlara bağlı olurlar. Şayet bir kısmı bedihî bir kısmı kesbî ise bu durumda da bedihî olan meseleler kesbî olanların ilkelerini oluşturur" (Kayserî, 2013, s. 41-42).

Tasavvuf ilmini, sıfat ve isimleri itibariyle Allah'1; ahiretin durumunu; âlemin hakikatlerini ve onun Allah'a dönüşünü; sülûk ve mücâhedenin yolunu ve nefsi tanımak (Kayserî, 2013, s. 43) şeklinde tanımlayıp, bu konuları itibariyle de onu ilimlerin en şereflisi ve yücesi olarak kabul eden Kayserî, onun konusunun Allah'ın zât1, ezelî ve ebedî sıfatları olduğunu belirtir (Kayserî, 2013, s. 42). Ona göre tasavvufun meseleleri ise, “Allah'ın zâtından kesretin sudûrunun ve tekrar O'na dönüşünün mahiyeti; ilahi isim ve Rabbânî vasıfların mazharlarının izahı; Allah'ın yolunda olanların O'na dönüşünün, sülûklarının, mücâhedenin ve riyazetlerinin mahiyetinin; dünya ve ahiretteki amel ve zikirlerin neticelerinin hakikatinin açılanmasıdır". Tasavvuf ilminin ilkelerine gelince bunlar, "onun tanımı ve faydası, bu ilmin terminolojisi ve bu ilimde araştırılacak olan şeylerin kendileri üzerine kurulacak bedihî olarak bilinen şeylerin bilgisidir (Kayserî, 2013, s. 42).”

Dâvûd-i Kayserî bu şekilde tasavvufta tatbik ettiği konu, ilke ve mesele metodolojisinde onun mevzu ve meselesi konusunda Konevî’yi takip ederken, ilkeleri hususunda ise ondan ayrılmıştır. Çünkü Konevî tasavvufun ilkeleri olarak Allah'ın isimlerini belirlerken Kayserî daha çok onun tanım, fayda, terminoloji ve meselelerin üzerine kurulacağı ön bilgileri ortaya koymaktadır. 
Seyyid Şerîf el-Cürcânî (ö. 816/1413) de bilimlerin konu, ilke ve meseleler ayrımı ilkesini kabul ederek bir ilmin kavranması için o ilmin tanımının yanında onun konu ve meselelerinin de tespitinin önemini vurgular. Ona göre ilimler konularıyla birbirinden ayrışır. Kelamın da onu diğer ilimlerden ayıran konusu "dinî inançların ispatının uzak veya yakın bir şekilde taalluk etmesi bakımından mâ‘lûmdur (Cürcânî, 2015, s. 136).” O, mâ‘lûmun durumunu izah ederken de onun varlığının, metafiziğin konusu olan mevcûdun varlığı gibi bizzât açık olup herhangi bir izaha ihtiyaç duymadığını ifade eder (Cürcânî, 2015, s. 142).

Curcânî, meselelerin bir ilmin maksatları ve hakikatleri olduğunu belirterek meselelerin amacı bazen kapalılığı ortadan kaldıracak bir dikkat çekmeye gerek duyma ya da bir nedenin izah edilmesi olduğunu vurgular (Cürcânî, 2015, s. 150)." Ona göre kelamın meseleleri "Yaratıcının kadîmliği, birliği, cisimlerin yaratılması ve tekrar tekrar yaratılabilirliğinin ispatı gibi dinî inanç ile cisimlerin atomlardan meydana gelmesi, boşluğun olabilirliği, hâlin reddi ve yok olabilen şeylerin ayrışmaması gibi söz konusu inançların dayanağını oluşturan önermelerdir (Cürcânî, 2015, s. 136).” O, bu meselelerden yola çıkarak da bunların konularını kuşatan şeyin de mevcûd, yokluk ve hâli de içine alan mâ‘lûm kavramı olduğunu (Cürcânî, 2015, s. 136) belirterek konu itibariyle tekrar mâ‘lûma atıfta bulunur.

Cürcânî, ilkelerin, söz konusu maksatlara -ki bu maksatlar meselelerdir- ulaştıran vesileler olduğunu belirterek, bunların tasavvurî ya da tasdîkî olacağını ifade eder. Şayet ilkeler çok fazla ihtiyaç duyulan bir şey olursa bazen ilmin bir parçası da sayılabilir (Cürcânî, 2015, s. 150). O, kelamın en yüce bilim olduğu düşüncesinden hareketle onun kendi ilkelerinin ya açılanmaya ihtiyaç duyulmayacak şekilde apaçık olduğunu ya da yine bu bilimde açıklandığını -ki bunlar da yine kelamın meseleleri ve kelamın başka meselelerinin ilkeleridir- ileri sürer (Cürcânî, 2015, s. 152).

Cürcânî’ye göre kelam ilminin en yüce ve en şerefli ilim olduğunu, bunun için bütün dinî ilimlerin konularının ve bu konuların hangi açıdan inceleneceğinin kelamda belirlendiğini belirtir. Buradan hareketle de ister dinî olsun ister olmasın kelam ilminin başka bir bilimde incelenecek ilkelerinin olmadığını ifade etmektedir (Cürcânî, 2015, s. 152). O, bu iddiasıyla İbn Sînâ’nın metafizik için ortaya koyduğu, onun en üstün bilim olması ve buradan hareketle diğer ilimlerin ilkelerinin kendisinde ortaya konulması hususunda kelamı metafiziğin yerine yerleştirmeye çalışmıştır. Bu anlayıştan hareketle de o, kelamın konusunu yalnızca Allah'ın varlığı ve inniyetine, meselelerini de O'nun sifatları ve âlemle ilişkisine hasreden Urmevî'yi Şerhu'l-mevâkıf'ta eleştirir (Cürcânî, 2015, s. 138-142).

İslam düşüncesinde Ortaçağ boyunca metafizik, kelam ve tasavvuf gibi ilimlere uygulanarak süregiden burhânî bilimlerin bu metodolojisini, İbn Haldûn (ö. 808/1406) Mukaddime'sinde, 'ümran' adında ortaya koyduğu yeni bir bilime tatbik etmeye çalışır. Her bilimin konu ve meselelerinin olduğunu, bir bilimin konu ve meselelerinin tespitinin o bilimi benzeri ve dengi olan diğer bilimden ayırmak olarak gören İbn Haldûn ümran ilmini "toplumla kaynaşmak ve ihtiyaçları gidermek amacıyla bir şehre ya da konaklama yerine inmek orada birlikte ikamet etmekten ibaret olduğunu (İbn Haldûn, 2011, s. 208)" belirterek, onun kendine has bir konusunun olduğunu ve onun da 'beşerî ümran ve insanî ictima' yani beşerî bir medeniyet ve insanî toplum olduğunu açılar (İbn Haldûn, 2011, s. 204). Yani ümran ilminin konusu toplumdur.

İbn Haldûn'a göre bir bilimin konusuna ilişen haller ve o konunun arâzları da o bilimin meselelerini oluşturur (İbn Haldûn, 2011, s. 2004). Bu bağlamda o, ümran ilminin meselelerini de topluma arız olan ve tabiatı gereği ümranda doğan durumlar olarak "vahşilik, ehlileşme, asabiyetler, insanların birbirine üstün gelme yolları, mülk, hanedanlıklar, bunların dereceleri, kazanç, geçim, ilimler, sanatlar, meslekler gibi şeyler" olarak sıralamaktadır (İbn Haldûn, 2011, s. 200). O, bunları "mülk, kazanç, ilimler ve sanatlar" şeklinde özetler (İbn Haldûn, 2011, s. 207).

Ümran ilminin ilkeleri ise Türker'in ifadesiyle İbn Haldûn'un Mukaddime'nin birinci babında belirttiği ümranın temelini oluşturan ilkelerdir. Türker'e göre bu ilkelerin tamamı aklî ilkeler olup siyaset, ahlak, coğrafya, metafizik, psikoloji gibi ilimlerde açıklanan meselelerdir (Türker, 2006, 3839). Bunlar:

1-İnsanların toplum halinde yaşamaları bir zarûrettir. 
2-Yeryüzündeki insan toplumlarının dağılımının dünyadaki orman, deniz, nehir ve iklim şartlarıyla ilişki ve bağlantısı vardır.

3-İklimin ılımlı olup olmaması ile insanların rengi ve mizacı arasında bir ilişki vardır.

4-İklimin insan ahlakı üzerinde bir tesiri vardır.

5-Bolluk ve kıtlığın insan bedeni ve ahlakı üzerinde etkisi vardır.

6-Gaybı idrak eden insanların bilgileri, onların doğuştan getirdiği bazı özelliklerin riyâzetle işlenmesi neticesinde oluşur (İbn Haldûn, 2011, s. 214-320; Türker, 2006, 39 ).

Bu şekilde İbn Haldûn'un ümran ilminin ilkelerini birisi coğrafyanın toplum birey üzerine etkisi biri de bedevî ve haydarî dikotomisi üzerine inşa ettiği görülmektedir.

\section{SONUÇ VE DEĞERLENDİRME}

Aristoteles ilk defa, burhânî bilimlerin konu, ilke ve mesele olmak üzere üç öğesinin olduğunu ortaya koymuştur. Onun bu ayrımını İslam felsefesinde ilk defa Fârâbî dile getirmiş; ancak bunu herhangi bir bilime tatbik etmemiştir.

İbn Sînâ, konu, ilke ve mesele ayrımı metodolojisini Burhân adlı eserinde ilk defa detaylı bir şekilde irdeleyerek sistematik bir hale getirmiştir. $\mathrm{O}$, bu çerçevede bilimlerin en yücesi olarak kabul ettiği metafiziğin konu, mesele ve ilkelerini de ilk defa ortaya koymuş ve metafiziği temellendirmiştir. Bilimler için bir çatı vazifesi gören bu üçlü ayrım, İbn Sînâ'dan sonra da İslam düşüncesinde kabul görmüş ve diğer bilimlere tatbik edilmiştir. Bu bağlamda, Gazzâî kelamın, Urmevî metafizik ve kelamın konu ve meselelerini ortaya koymuştur. Daha sonra bu sistem, Cürcânî tarafindan en üstün ve yüce bir ilim olarak görülen kelama; Konevî ve sonrasında Dâvûd-i Kayserî tarafından tasavvufa tatbik edilirken; İbn Haldun ise bununla, yeni bir bilim olarak ortaya koyduğu ümran ilmini temellendirmeye çalışmıştır.

Ortaçağ boyunca İslam düşüncesinde revaçta olup bu şekilde süregelen bu metodolojinin günümüz bilim anlayışındaki yeri nedir? Rönesans'tan sonra Batı dünyasında bilhassa tabiat bilimlerinde hızlı gelişmeler yaşandı ve XVI. ve XIX. yüzyılları arasında fizik, kimya, biyoloji, jeoloji gibi bilimler konuları itibariyle çerçevesi belirlenmiş bağımsız birer bilim haline geldiler. Aynı şekilde XVIII. yüzyılın sonları ve XIX. yüzyılda sosyal bilimler alanında da sosyoloji, psikoloji, ekonomi, sosyal antropoloji gibi bilimler ortaya çıktı ve her bilim kendi metodolojisini geliştirdi. (Rickman, 2000, s. 20). Aristoteles ile başlayıp Ortaçağ boyunca kabul gören konu, ilke, mesele ayrımı gerek fen gerekse de sosyal alanlarda bağımsız birer bilim dalı olarak ortaya çıkan modern bilimlerde de kabul görmüş ve bir bilimin müstakil bir bilim dalı olmasında vazgeçilmez bir unsur olmaya devam etmiştir. Öyle ki bir bilimin konusu ve onda ele alınan temel problemler ve meseleler bir bilim dalını diğerlerinden ayıran temel hususlar olarak telakkî edilmiştir.

İlk ve Ortaçağ'da bilimler için kabul edilen temel mantık ilkeleri -ki bunlar Aristoteles ve İbn Sînâ tarafından ortaya konulan genel ve özel ilkelerdir- evrensel bilim anlayışı çerçevesinde ve ilgili bilim dalının temel özellikleri bağlamında daha da özelleşmeye başladı. Bunun yanında bilimsel bir araştırmada takip edilen yol olan -ki bu İlk ve Ortaçağ'da Aristoteles mantığındaki kıyastır- yöntem, modern bilim anlayışında hem değişerek hem de gelişerek önemli bir unsur olarak yerini aldı. Yöntem günümüzde genel itibariyle anket, gözlem, deney, gibi nicel olabileceği gibi anlama, yorumlama, doküman inceleme gibi nitel de olabilmektedir. Buradan hareketle örnek olarak sosyoloji bilimini ele aldığımızda onun konusu toplum; onun temel meseleleri ya da kendine problem ettiği temel inceleme alanları da toluma ilişen toplumsal olaylar, toplumsal kurumlar, toplumsal ilişkiler ve toplumsal yapılardır (Güven, 1999, s. 4 ). Bir araştırmacının sosyolojinin meselelerini incelerken uyacağı temel ilkeler özetle; "-Ele alınan sosyal durum belirli ve sinırlı olmalıdır. -Sosyal bir olay veya olgu objektif bir bakış açısıyla ele alınmalıdır. -Toplumsal bir olgu veya olay net olarak ortaya konulmalıdır. Sosyal bir olay bütüncül bir bakışla ele alınmalıdır. -Toplumsal bir olayın sebebi yine bir toplumsal olaydır. -Sosyoloji olması gerekeni değil, olanı inceler" (Taplamacıoğlu, 1969, s. 46-51) iken sosyolojik bir mesele araştırırken takip edilen yöntem de araştırılacak meselenin özelliğine göre nicel ya da nitel olabileceği gibi hem nicel hem de nitel olabilmektedir. Bu şekilde sosyoloji konusu, temel meseleleri, ilkeleri ve yöntemiyle müstakil bir bilim olarak kendini ortaya koymaktadır. 
Bilgilendirme / Acknowledgement: Bu makalenin sadece 1. bölümü kısmen "Dânişnâme-i'Alâ̂̀'de İbn Sînâ Metafiziği” adlı doktora tezimizden alınıp yeniden değerlendirilerek hazırlanmıştır.

\section{KAYNAKÇA}

Aristoteles. (2010). Metafizik. (çev. A. Arslan). İstanbul: Sosyal Yayınları.

Aristoteles. (1991). Posterior analytics. Jonathan Barnes (edit.). Complete works of Aristotle içinde. Princeton: Princeton University Press.

Cürcânî, S. Ş. (2015). Şerhu'l-mevâklf. I-II-III. (çev. Ömer Türker). İstanbul: Türkiye Yazma Eserler Kurumu Başkanlığı Yayınları.

Daşdemir, Y. (2012). İbn Sina mantığında burhanî bilimlerin konu, ilke ve problemleri. Felsefe Dünyast, 55(1), 240-261.

Demirli, E. (2007). 'Varlık olmak bakımından varlık' ifadesinin sûfilerce yeniden yorumlanması ve bu yorumun metafizik sonuçları. Íslam Araştırmaları Dergisi, 18, 27-47.

Fârâbî. (2012). Kitâbu'l-burhân. (çev. Ö. Türker ve Ö.M.Alper). İstanbul: Klasik Yayınları.

Gazzâlî, E. H. (1994). el-Mustasfâ. I-II. (çev. Yunus Apaydın). İstanbul: Klasik Yayınları.

Güven, S. (1999). Toplumbilim. Bursa: Ezgi Kitabevi.

Hânsârî, M. (1356 (hş.)). İlâhiyyât ez nazar-i İbn-i Sînâ, Zemîme Mecelle-i Dânışkede-i Edebiyât $\hat{u}$ Ulûm-i İnsânî-yi Dânişgâh-ı Tahrân, 3, 1-17.

İbn Haldûn. (2011). Mukaddime. (çev. Süleyman Uludağ). İstanbul: Dergâh Yayınları.

İbn Sînâ. (1383/2004). Dânişnâme-i 'alâî: Illâhiyyât. (thk. Muhammed Mu'în). Hemedân: Dânişgâh-i Bû Alî Sînâ.

İbn Sînâ. (1391(hş.). Dânişnâme-i 'alâi: Mantık. Risâle-i mantık-ı Dânişnâme-i 'Alâî içinde. (tsh. Nevâb Mekrabî). Tahrân: Bunyâd-i Hikmet-i İslâmî-yi Sadrâ.

İbn Sînâ. (2005). el-İşârât ve't-tembîhât. (çev. A. Durusoy, M. Macit ve E. Demirli). İstanbul: Litera Yayınları.

İbn Sînâ. (1992). en-Necât fíl'l-mantık ve'l-ilâhiyyât. I-II. (thk. Abdurrahman Umeyra). Beyrut: Daru'lCîl.

İbn Sînâ. (2006). eş-Şifâ: II. Analitikler/burhân. (çev. Ö. Türker). İstanbul: Litera Yayınları.

İbn Sînâ. (2005). eş-Şifâ:Ilâhiyyât the metaphysics of the Healing, a parallel English-Arabic text. (trans. M. Marmura). Utah: Brigham Young University Press.

Kayserî, D. (2013). Risâle fi ilmi't-Tasavvuf ve şerhu te'vilatı besmele. (çev. M.Bedirhan). İstanbul: Nefes Yayınları.

Konevî, S. (2002). Miftâh-ı gaybi'l-cem ve'l-vücûd. (çev. Ekrem Demirli). İstanbul: İz Yayıncılık.

Kutluer, İ. (2002). İbn Sinâ ontolojisinde zorunlu varlık. İstanbul: İz Yayınları.

Mekrabî, N. (1391 (hş.)). Şerh-i kıt'ahâ-yi risâle-i mantık. Risâle-i mantık-ı danişnâme-i 'alâi içinde. Tahrân: Bunyâd-i Hikmet-i İslâmî-yi Sadrâ.

Rickman, H.P. (2000). Anlama ve insan bilimleri. (çev. M. Dağ). Samsun: Etüt Yayınları.

Taplamacioğlu, M. (1969). Genel sosyoloji üzerine bir deneme. Ankara: Ankara Üniversitesi İlahiyat Fakültesi Yayınları.

Türker, Ö. (2008). 'Birden bir çıkar' ilkesinin Sadreddin Konevî tarafindan yorumlanması. I. Uluslararası Sadreddin Konevî Sempozyumu Bildirileri içinde. (s. 233-236). Konya: Mebkam Yayınları. 
Türker, Ö. (2014). Metafizik nedir? İbn Sînâ'nın Kitâbu'ş-şifâ el-İlâhiyyât'ı bağlamında bir tahlil. Diyanet İlmi Dergi, 50(1), 15-26.

Türker, Ö. (2006). Mukaddime'de akli ilimler algısı: İbn Haldûn'un 'bireysel yetenekler' teorisi. İslam Araştırmaları Dergisi, 15, 33-50.

Urmevî, S. (2009). Risâletü fî’l farki'l beyne nev'ey el-ilmi'l-ìlâhî. (thk. Burhan Köroğlu). Marmara Üniversitesi İlahiyat Fakültesi Dergisi, 36, 95-106. 